\title{
Some Nigerian Traditional Food Milling Techniques and Cookware Increase Concentrations of Some Heavy Metals in Lycopersicon Esculentum and Citrullus Lanatus
}

\author{
Anthony,B.Ojekale ${ }^{1}$, Chioma. G.Chukwu ${ }^{2}$, Oladipupo.O.Lawal. ${ }^{3}$ and \\ Titilola.S.Osinaike ${ }^{4}$ \\ ${ }^{1,2}$ Department of Biochemistry, Lagos State University, Ojo, Lagos, Nigeria, \\ ${ }^{3}$ Department of Chemistry, Lagos State University, Ojo, Lagos, Nigeria, \\ ,4, Department of Botany, Lagos State University, Ojo, Lagos, Nigeria, \\ PMB 0001, LASU Post office, Ojo, Lagos, Nigeria
}

\begin{abstract}
The heavy metal contamination of Lycopersicon esculentum and Citrullus lanatus by different milling techniques and cookwares are reported in this study. Heavy metal analysis of iron, zinc, copper, lead, cadmium and aluminium were carried out using atomic absorption spectrophotometer [AAS]. Results show that of all the milling processes used in this study; the locally fabricated milling machine added the highest concentration of Fe to food. This value of $11.625 \mathrm{mg} / \mathrm{kg}$ is below the recommended dietary allowance (RDA) and tolerable upper intake levels $(U L)$ for iron, but after cooking with the locally made iron pot, earthenware pot and stainless steel pot, the concentration of iron contamination in the sample increased from $11.625 \mathrm{mg} / \mathrm{kg}$ to $21.445 \mathrm{mg} / \mathrm{kg}$, $18.375 \mathrm{mg} / \mathrm{kg}$ and $13.775 \mathrm{mg} / \mathrm{kg}$ respectively indicating that the locally made iron pot added a significant concentration of iron to foods cooked in it higher than the RDA, and posing a risk of iron over load to man. The values of $\mathrm{Cu}, \mathrm{Cd}$ and $\mathrm{Zn}$ contamination in analyzed samples are within recommended dietary allowance. Lead was not detected in any of the samples analyzed. Aluminium was observed only in samples cooked with locally fabricated iron pot. The values range from $0.4 \mathrm{mg} / \mathrm{kg}-1.63 \mathrm{mg} / \mathrm{kg}$, suggesting a risk of Al toxicity, as the upper range exceeds the WHO limit of $1 \mathrm{mg} / \mathrm{kg}$.
\end{abstract}

Keywords: Milling, cookware, heavy metals, Lycopersicon esculentum and Citrullus lanatus

\section{INTRODUCTION}

Mankind since early times, especially after the discovery of "making fire" had always milled and cooked using different milling techniques and (cookware) utensils. These varied in type and sophistication from one geographical location to another. The tradition, culture and level of civilization of a people contributed immensely to their milling tools and cookware. Contamination of food by heavy metals is of paramount concern to public health, as food is the primary source of essential nutrients for man [Pennington, 2000,Jigam et $a l, 2011$,$] . Monitoring the presence of heavy metals in foods intended both for human and wildlife is of interest$ because of their toxic effects, as heavy metals bioaccumulate and pose health risks [Cabrera et al., 2003]. Some heavy metals have important biochemical functions like zinc, copper, nickel and iron, but can also have harmful effects when their intake exceeds the recommended limits [www.foodquality.com; Llobet et al, 2003; Jimoh et $a l, 2012]$. Aluminum, mercury, lead, cadmium, etc. are non-nutrient metals which can be toxic even in trace amounts [Somers, 1974]. Generally, heavy metals disrupt basic metabolic functions in two ways: on one hand, they disrupt the functioning of vital organs and glands such as the heart, brain, kidney, bone or liver, on the other hand, they move nutrients that are essential minerals and prevent them from fulfilling their biological functions. For example, aluminum as a chelator has the ability to capture and prevent the uptake of essential elements such as calcium, zinc and copper, and disrupt the proper use of many of them [Dabonne et al,2010]. This metal is heavily involved in the onset of Alzheimer's disease. It is responsible for the alteration of neurons [Miu and Beng, 2006; Bharathi et al., 2008]. Depending on the heavy metal in question, toxicity can occur at levels just above naturally occurring background levels, meaning that consumption of foods with a high heavy metal concentration can cause acute or chronic poisoning [Llobet et al, 2003]. Poisoning can result in damaged or reduced mental and central nervous function, as well as damage to blood composition, lungs, kidneys, liver, and other vital organs. Long-term exposure to heavy metals may result in slowly progressing physical, muscular, and neurological degenerative conditions as well as cancer [Llobet et al, 2003]. 
The most frequently reported heavy metals with regard to potential hazard and occurrence in contaminated food samples are copper $(\mathrm{Cu})$, lead $(\mathrm{Pb})$, zinc $(\mathrm{Zn})$, nickel $(\mathrm{Ni})$, cobalt $(\mathrm{Co})$, chromium $(\mathrm{Cr})$, iron (Fe), cadmium (cd) [ Ehiri et al, 2010].Sources of heavy metal contamination of food include soil, water used for agricultural irrigation including rainfall, and processes in the different stages of agricultural production as they are natural constituents of the earth crust [Elekofehinti et al, 2012, Dabonne et al, 2010]. Other sources of food contamination by heavy metals include techniques and materials used in food processing and transformation [Ehiri et al 2010, Dabonne 2010]. The transformation process involves the use of cookwares that contaminate food with heavy metals based on the materials of their design [Cabrera et al., 2003].Food processing methods involve lots of operations, which include coarse grinding of food material called size reduction [www.fitzmill.com ]. Grinding of foods (size reduction) as part of food processing operation in the past was completely done by using traditional methods, which include stones, bricks, pestle and mortar [Yahaya et al, 2012]. These methods were effective but rather slow, time consuming and unhygienic [Ehiri et al, 2010]. As the need of the people for food increase, new technologies were developed and modern methods of grinding foods were invented such as blenders, mills and crushers. These mills make use of toughened steel, stones and hardened steel, toothed discs. Foods processed using locally fabricated mill were sometimes found to be mixing up with contaminants such as heavy metals [Yahaya et al, 2012, Somers, 1974]. The determination of trace elements particularly heavy metals such as arsenic, mercury, chromium, iron, lead, cadmium, cobalt, copper, manganese, nickel, zinc, etc. have received increasing attention in food chemistry, nutrition, and pollution studies.

In Nigeria, as in most developing countries, much of the urban population and almost all rural population still use traditional cookwares. Examples are the clay and aluminum pots. Unlike stainless steel wares, traditional wares are designed with impure materials which may be toxic and leach into foods. They do not have a protective layer of inert material to prevent contamination of food [Rajwanshi et al, 1997]. The majority of reports (REFERENCES) on the uptake of heavy metals by plants in the public domain concentrate on the uptake of such heavy metals from the soil. This study concentrated on how milling techniques and cookware contribute to the levels of heavy metals of food materials processed in them. Tomatoes and melon were selected for this research, as they are essential part of the Nigerian diet [Pennington, 2000 ] and also due to their wide usage as sources of vitamins, minerals, protein and oils [Younis et al,2000, Murkovic et al,1996].

\section{MATERIALS AND METHODS}

\subsection{Sample Collection}

Fresh samples of Lycopersicon esculentum and Citrullus lanatus were procured from Igando market in Lagos, South west Nigeria (latitude 6.54992, longitude 3.24345). Plant samples were identified by, a taxonomist in Botany Department, Lagos state university Ojo, Lagos.

\subsection{Sample preparation}

The Lycopersicon esculentum (tomatoes) was washed with distilled deionized water, while the Citrullus lanatus (melon seeds) was cleaned by picking out sand, stones, and other abrasive materials. The cleaned samples were divided into four groups, and each group was milled separately with one of the following grinding tools

a. wooden mortar and pestle,

b. locally fabricated milling machine,

c. grinding stone, and

d. commercially available domestic blender. (control)

A

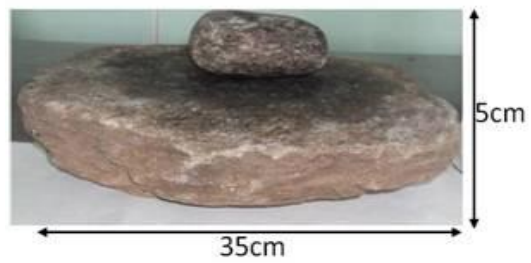

B

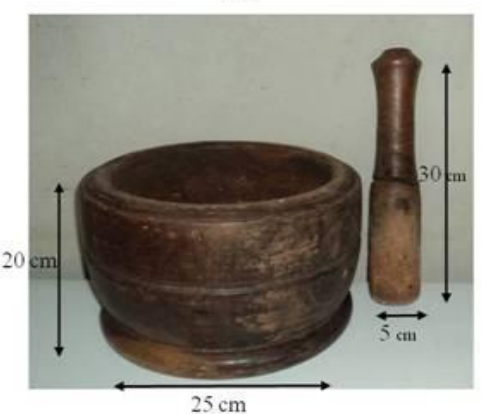

C

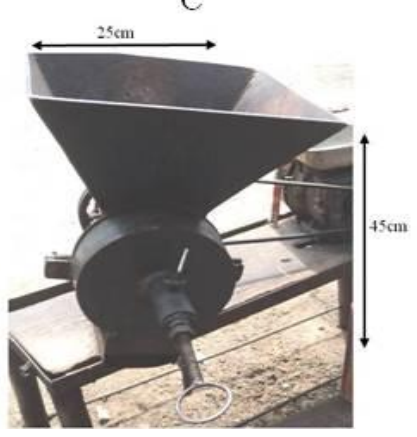

Figure 1: (a) grinding stone, (b) wooden mortar and pestle, (c) locally fabricated grinding machine 

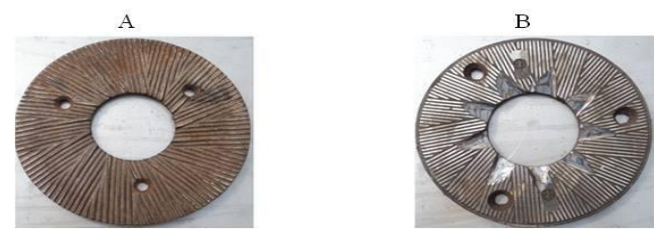

Figure 2: Grinding discs (a) new, (b) worn \{used\} for locally fabricated grinding machine (see Fig 1.C)

Milled samples from each group above were cooked for an average of 15minutes in 3 different cookware namely:-

a locally manufactured iron pot,

b. earthenware pot, and

c. stainless steel pot.
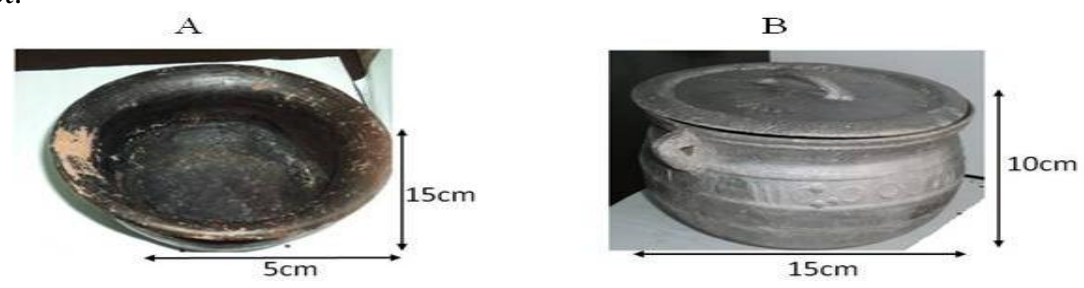

Figure 3: (a) earthenware pot, (b) locally made iron pot

The milled and cooked samples were collected in labeled sterile containers.

\subsection{Sample digestion}

Samples were digested according to the method described by the Association of Official Analytical Chemists [AOAC, 2006]. Briefly, $5 \mathrm{~g}$ of each sample was weighed into $250 \mathrm{ml}$ conical flask, $10 \mathrm{ml}$ aqua regia (nitric acid and $\mathrm{HCl}$ in a ratio of 1:3) was added, and the mixture was evaporated on a hot plate in a fume cup board until the black fume disappeared leaving the white fume. The resulting sample was then made up to $50 \mathrm{ml}$ using distilled deionised water and then filtered into a clean universal bottle for atomic absorption spectrometric analysis [AOAC, 2006].

\subsection{Heavy metal analysis}

The heavy metal analysis of the digested samples was done using a Perkin Elmer A Analyst 400 Atomic Absorption Spectrometer to aspirate for the presence of heavy metals. Standard addition technique (SAT) was used to calibrate the instrument in order to check and correct matrix. Standards were prepared by serial dilution techniques within the range of each metal determined. The standards used were Analar grade. The instrument was first calibrated with stock solutions of the prepared standards before the analysis.

\section{RESULTS}

Atomic absorption spectrophotometric analysis of heavy metals present in food samples processed differently with locally fabricated milling machine, grinding stone, blender (NAKAI JAPAN 262), mortar and pestle and cooked using iron pot, earthernware pot and stainless steel pot are illustrated below.

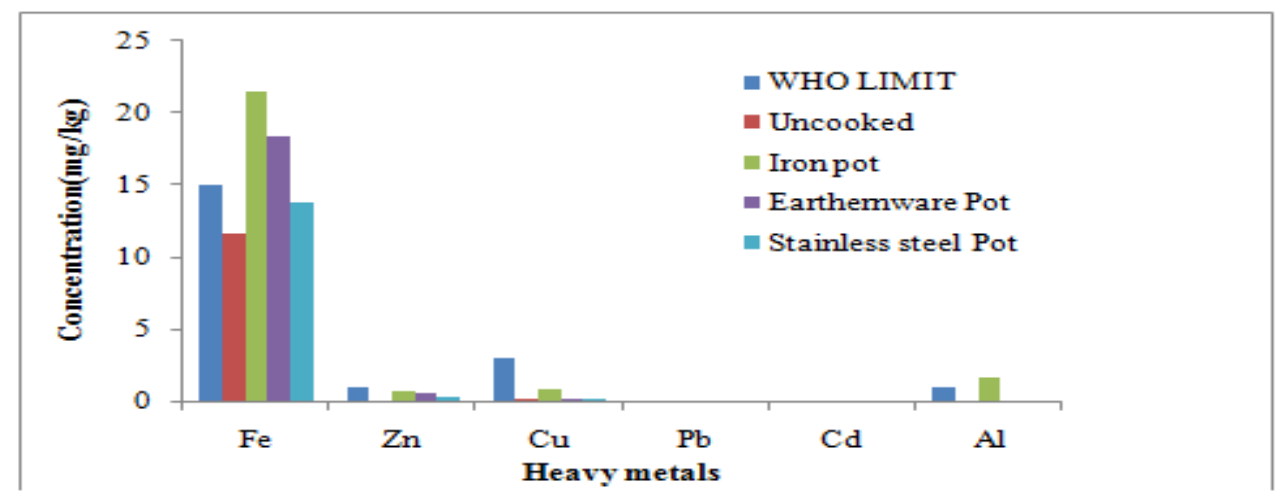

Figure 4: Comparative concentration of selected heavy metals in Lycopersicon esculentum milled by a locally fabricated "milling machine and cooked using different cookware. 


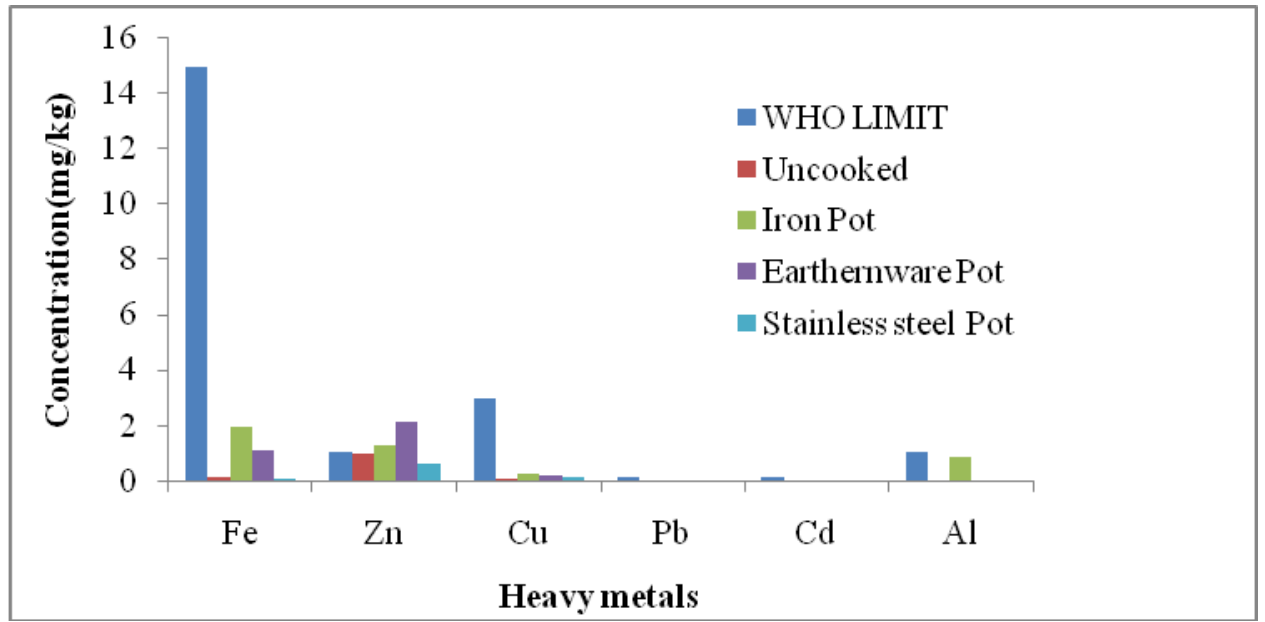

Figure 5: Comparative concentrations of selected heavy metals in Lycopersicon esculentum milled by mortar and pestle and cooked using different cookware.

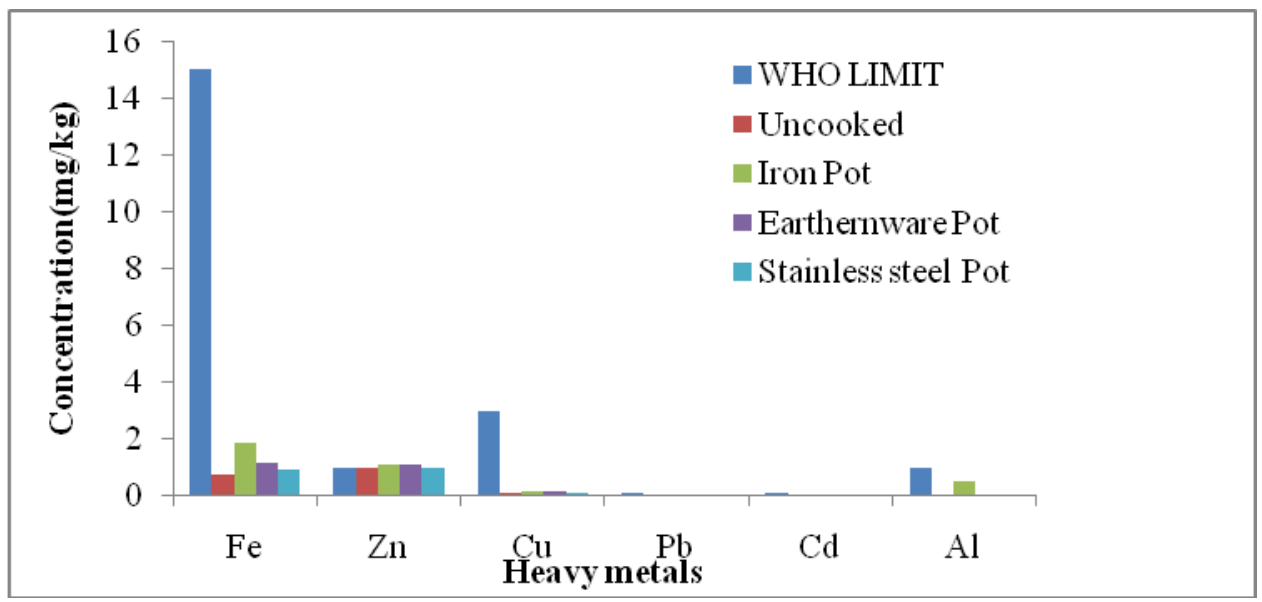

Figure 6: Comparative concentration of selected heavy metals in Lycopersicon esculentum milled by grinding stone and cooked using different cookware

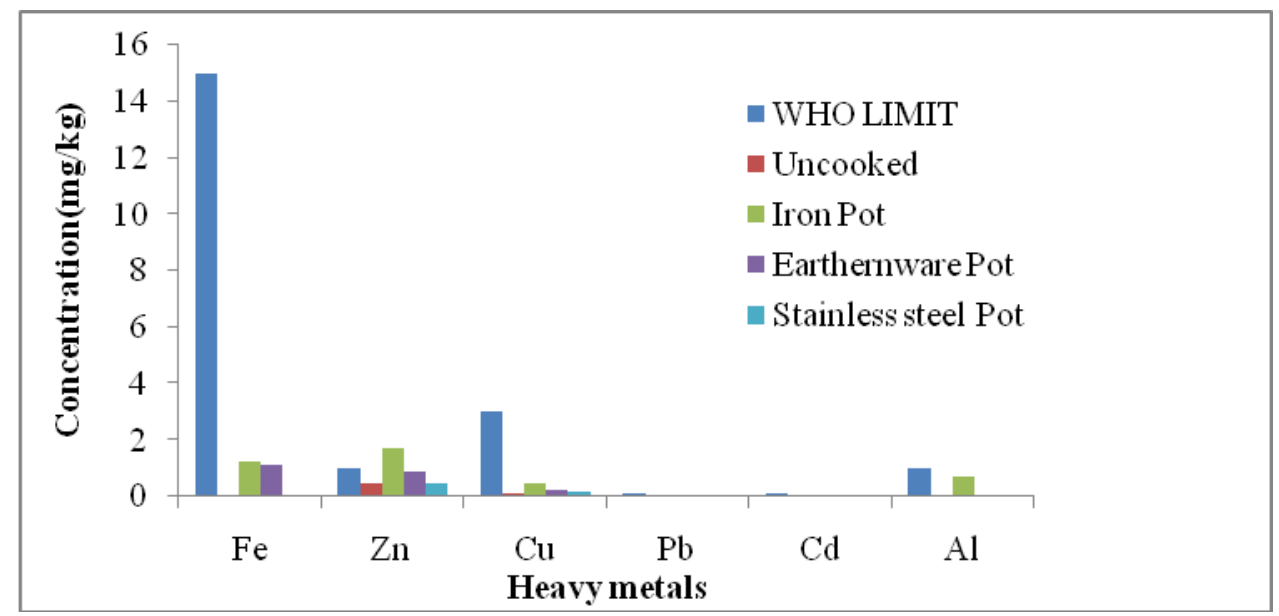

Figure 7. Comparative concentration of selected heavy metals in Lycopersicon esculentum milled by blender, and cooked using different cookware 


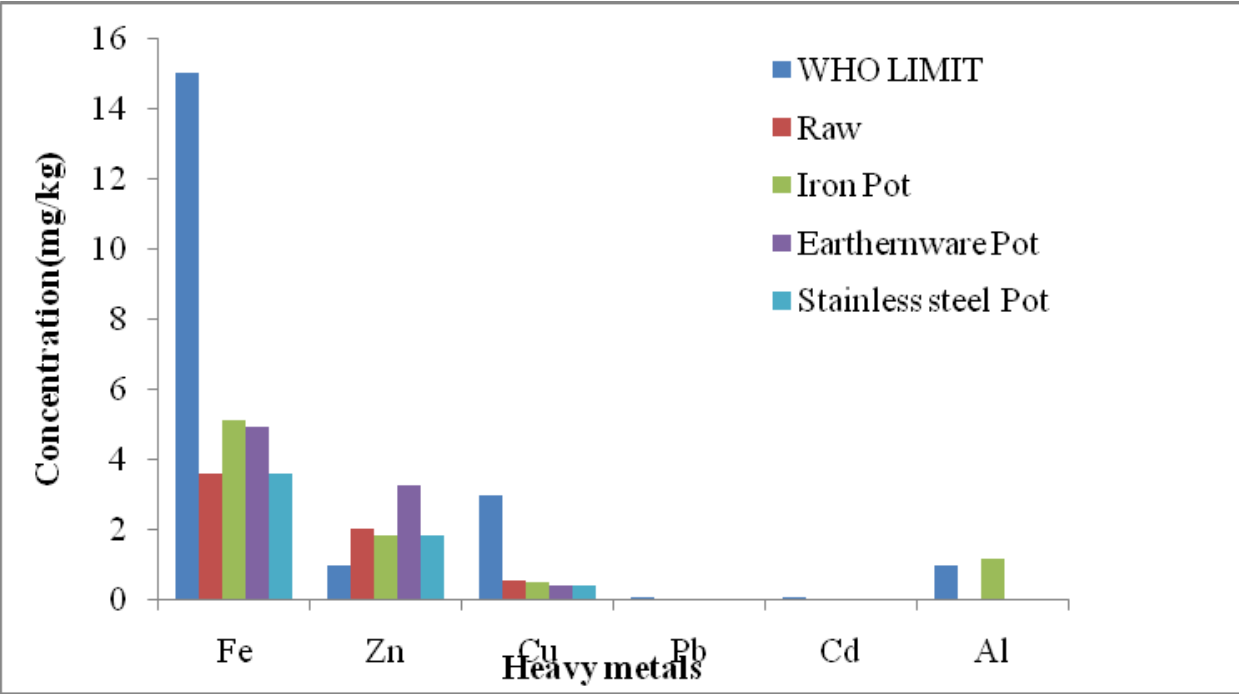

Figure 8: Comparative concentration of selected heavy metals in Citrullus lanatus milled by locally fabricated milling machine, and cooked using different cookware.

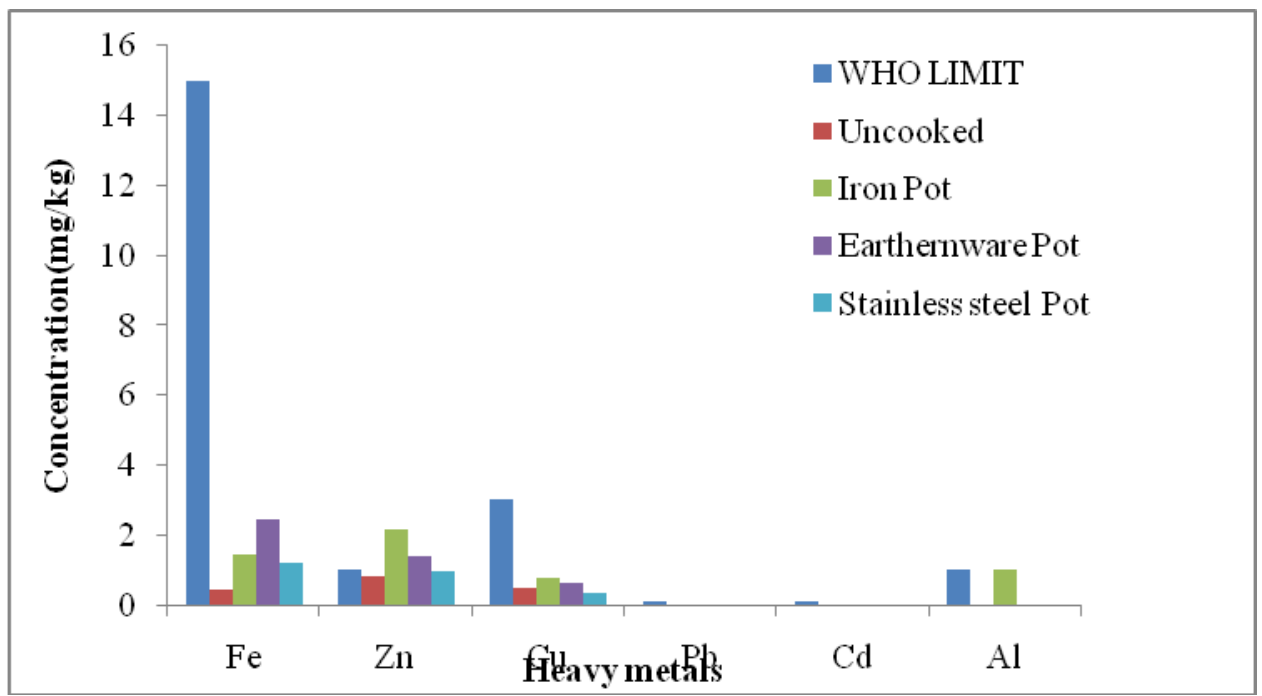

Figure 9: Comparative concentration of selected heavy metals in Citrullus lanatus milled mortar and pestle, and cooked using different cookware

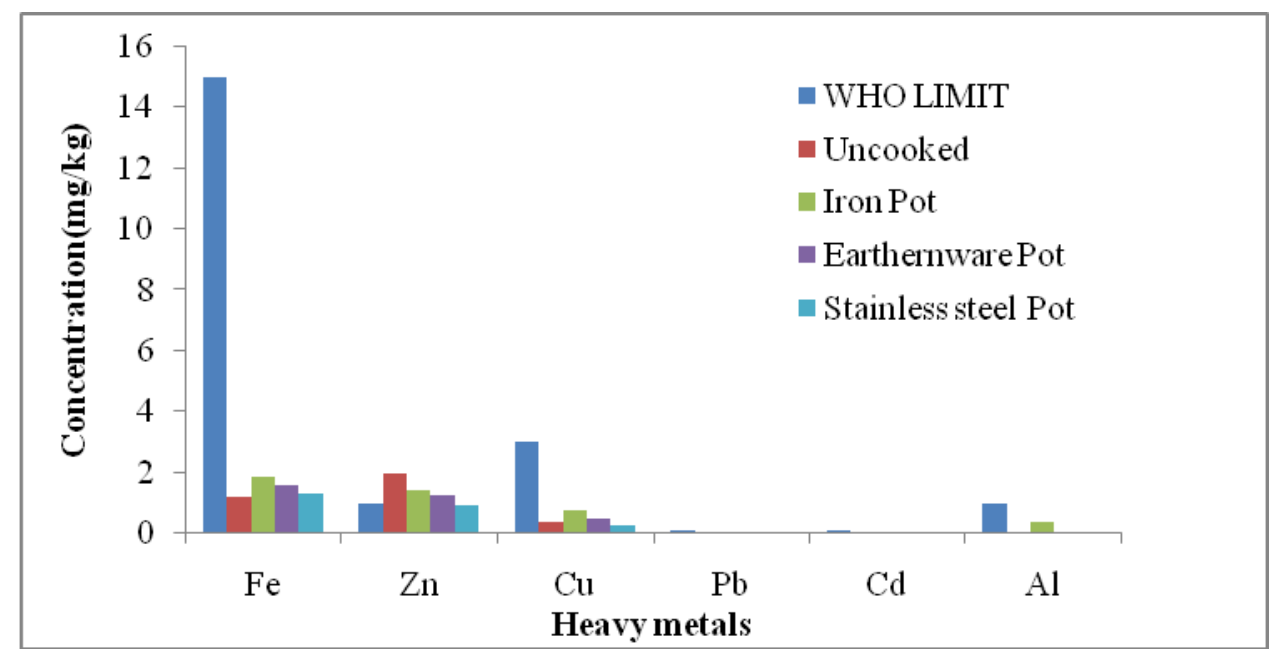

Figure 10: Comparative concentration of selected heavy metals in Citrullus lanatus milled using grinding stone, and cooked using different cookware 


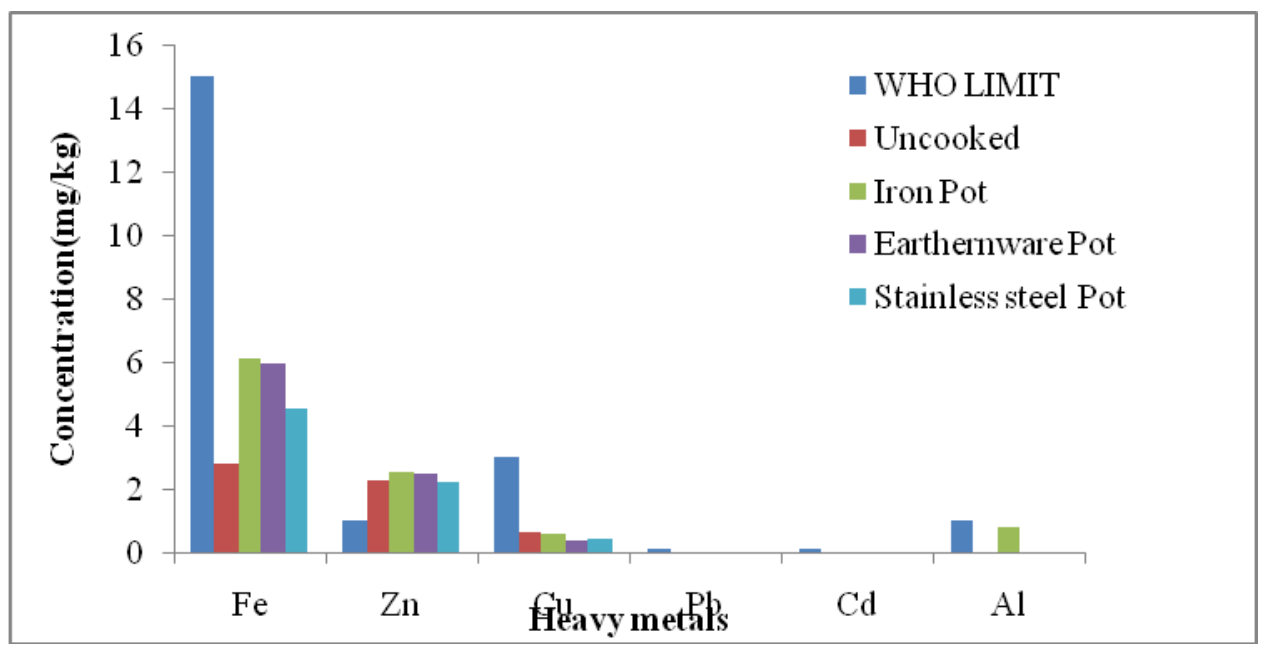

Figure 11: Comparative concentration of selected heavy metals in Citrullus lanatus milled blender, and cooked using different cookware

\section{DISCUSSION}

The results of atomic absorption spectrophotometric analysis of the concentration of heavy metals present in food samples processed with different types of milling equipments, viz locally fabricated milling machine, grinding stone, blender, mortar and pestle and cooked using locally made iron pot, earthernware pot and stainless steel pot are shown in fig 4 - 11. Generally, the increase in concentration of the heavy metals in the experimental sample over the control (milled using a commercially procured blender and cooked in stainless steel pot) sample represents the amount of heavy metal added by the various cookware and milling techniques. The results indicate that the amount of Fe added by the locally fabricated milling machine, grinding stone mortar and pestle, and blender to Lycopersicon esculentum were $11.625 \mathrm{mg} / \mathrm{kg}, 0.769 \mathrm{mg} / \mathrm{kg}, 0.099 \mathrm{mg} / \mathrm{kg}$ and $-0.003 \mathrm{mg} / \mathrm{kg}$ respectively (see fig 4). This shows that the locally fabricated milling machine has the highest value of iron added to food while the blender adeded the lowest value of $-0.003 \mathrm{mg} / \mathrm{kg}$ as Fe was not detected in the sample. The high concentration of Fe in lycopersicon esculentum milled using locally fabricated milling machine could be attributed to the abrasive friction of the grinding disc as the food sample comes in contact with it during grinding which results to its chipping off into the milled sample [Yahaya et al, 2012]. A simple comparison of a new grinding disc and an old one (fig.2) highlights the possible chipping of metals into food samples ground by milling machine.

Results of cooked Lycopersicon esculentum samples using iron pot, earthern ware pot and stainless steel pot after milling with locally fabricated milling machine show that the concentration of Fe added by the different cookwares increased from $11.665 \mathrm{mg} / \mathrm{kg}$ to $21.445 \mathrm{mg} / \mathrm{kg}, 18.375 \mathrm{mg} / \mathrm{kg}, 13.775 \mathrm{mg} / \mathrm{kg}$ respectively, while that of citrullus lanatus increased from $3.605 \mathrm{mg} / \mathrm{kg}$ to $5.138 \mathrm{mg} / \mathrm{kg}, 4.909 \mathrm{mg} / \mathrm{kg}$ and $3.626 \mathrm{mg} / \mathrm{kg}$, respectively(see fig.8). This indicates that the locally made iron pot(fig 3B) added the highest concentration of Fe to the food samples while stainless steel pot had the lowest value of Fe contamination. This can be attributed to leaching from the cookware which makes the local iron and earthernware pots potential sources of heavy metal contamination of food. The concentration of iron detected in this study is higher than standard limits recommended by international regulations. Although, iron is very important in biological system because of its ability to form complexes and exist in different oxidation states, it is also present in blood pigment hemoglobin which is able to become reversibly bonded by forming coordinate bonds with oxygen molecular thus allowing hemoglobin to transport oxygen to all part of the body and release it where it is needed (Gupta, 2005). Excess iron in the body can increase the risk of cardiovascular disease (Gupta, 2005). The results of Fe contamination in cooked Lycopersicon esculentum samples using iron pot, earthern ware pot and stainless steel pot after milling with mortar and pestle (fig.5) show that the concentration of Fe added by the different cookwares increased from $0.099 \mathrm{mg} / \mathrm{kg}$ to $1.947 \mathrm{mg} / \mathrm{kg}, 1.09 \mathrm{mg} / \mathrm{kg}$ and $0.09 \mathrm{mg} / \mathrm{kg}$ respectively, while that of citrullus lanatus increased from $0.43 \mathrm{mg} / \mathrm{kg}$ to $1.427 \mathrm{mg} / \mathrm{kg}, 2.453 \mathrm{mg} / \mathrm{kg}$ and $1.218 \mathrm{mg} / \mathrm{kg}$. This suggests that there is minimal risk of iron intoxication from using mortar and pestle for milling food, as the concentration of Fe added to the food sample is minimal compared to the WHO recommended limit of $15 \mathrm{mg} / \mathrm{kg}$. Also, the presence of iron in the soil and the natural phenomenon of metal accumulation in some plants (Harrigton, 1994; Zhuang et al., 2009) could also contribute to this value which may not originate from the milling technique. 
The zinc added by the locally fabricated milling machine, mortar and pestle, grinding stone and blender to Lycopersicon esculentum (Fig 4 - 7) were $0.018 \mathrm{mg} / \mathrm{kg}, 0.986 \mathrm{mg} / \mathrm{kg}, 1.012 \mathrm{mg} / \mathrm{kg}$ and $0.487 \mathrm{mg} / \mathrm{kg}$ respectively and that of citrullus lanatus were $2.022 \mathrm{mg} / \mathrm{kg}, 0.822 \mathrm{mg} / \mathrm{kg}, 1.925 \mathrm{mg} / \mathrm{kg}$ and $2.288 \mathrm{mg} / \mathrm{kg}$, respectively. This suggests that grinding stone and milling machine added the highest level of zinc to the food samples while the blender added the least. These values are within recommended WHO limit and thus pose minimal risk of $\mathrm{Zn}$ intoxication. However, the $\mathrm{Zn}$ concentrations increased after cooking the Lycopersicon esculentum using iron pot, earthern ware pot and stainless steel pot. Values for cooked samples of locally fabricated milling machine milled Lycopersicon esculentum increased from $0.018 \mathrm{mg} / \mathrm{kg}$ to $0.718 \mathrm{mg} / \mathrm{kg}, 0.515$ $\mathrm{mg} / \mathrm{kg}$ and $0.208 \mathrm{mg} / \mathrm{kg}$ respectively, while that of citrullus lanatus increased from $2.022 \mathrm{mg} / \mathrm{kg}$ to $3.238 \mathrm{mg} / \mathrm{kg}$ for earthern ware pot and decreased to 1.874 and 1.853 for aluminium and stainless steel pots respectively. These values are also within WHO limits and do not pose any health risks. Results of cooked samples of mortar and pestle milled Lycopersicon esculentum increased from $0.986 \mathrm{mg} / \mathrm{kg}$ to $1.27 \mathrm{mg} / \mathrm{kg}, 2.143 \mathrm{mg} / \mathrm{kg}$ and 0.632 $\mathrm{mg} / \mathrm{kg}$. This indicates that samples cooked with earthen ware pot pose a risk of zinc intoxication, as its concentration is 2 times higher than the standard limit of $1 \mathrm{mg} / \mathrm{kg}$. For citrullus lanatus; values increased from $0.822 \mathrm{mg} / \mathrm{kg}$ to $2.142 \mathrm{mg} / \mathrm{kg}, 1.395 \mathrm{mg} / \mathrm{kg}$ and $0.951 \mathrm{mg} / \mathrm{kg}$ for aluminium, earthern ware and stainless steel pots respectively. This result suggests that consistent use of earthern ware pot to cook food milled using mortar and pestle carry the risk of causing zinc toxicity. This may interfere with other minerals in the body, especially, iron and copper [Liang et al, 2004]. Hence, the possibility of severe anemia with deficiency of vitamin D and calcium. Excess Zinc in the body also causes osteoporosis and osteomalacia [Liang et al, 2004].Grinding stone milled Lycopersicon esculentum increased from $1.012 \mathrm{mg} / \mathrm{kg}$ to $1.133 \mathrm{mg} / \mathrm{kg}, 1.13 \mathrm{mg} / \mathrm{kg}$ and $1.021 \mathrm{mg} / \mathrm{kg}$ after cooking with iron pot, earthern ware pot and stainless steel pot respectively, while that of citrullus lanatus increased from $1.925 \mathrm{mg} / \mathrm{kg}$ to $1.429 \mathrm{mg} / \mathrm{kg}, 1.28 \mathrm{mg} / \mathrm{kg}$ and $0.944 \mathrm{mg} / \mathrm{kg}$. These values are slightly within WHO recommended limit and do not pose any risk of zinc intoxication.

Results of copper analysis in Lycopersicon esculentum milled with locally fabricated milling machine, mortar and pestle, grinding stone and blender (fig 4-7) were $0.107 \mathrm{mg} / \mathrm{kg}, 0.07 \mathrm{mg} / \mathrm{kg}, 0.1 \mathrm{mg} / \mathrm{kg}$ and 0.121 $\mathrm{mg} / \mathrm{kg}$ while that of citrullus lanatus (Fig 8 - 11) were $0.5872 \mathrm{mg} / \mathrm{kg}, 0.822 \mathrm{mg} / \mathrm{kg}, 0.3332 \mathrm{mg} / \mathrm{kg}$ and 0.6282 $\mathrm{mg} / \mathrm{kg}$ respectively. These values indicate that none of the milling techniques used in the size reduction of Lycopersicon esculentum and citrullus lanatus have the potential of causing any health issues. Additionally, the presence of copper in the soil and the natural phenomenon of metal accumulation in some plants (Harrigton, 1994; Zhuang et al., 2009) could also contribute to this values which may not originate from any of the milling techniques. After cooking the Lycopersicon esculentum with iron pot, earthern ware pot, and stainless steel pot, the sample milled with locally fabricated milling machine increased from $0.107 \mathrm{mg} / \mathrm{kg}$ to $0.747 \mathrm{mg} / \mathrm{kg}, 0.161$ $\mathrm{mg} / \mathrm{kg}$ and $0.121 \mathrm{mg} / \mathrm{kg}$ respectively, while citrullus lanatus increased from $0.5872 \mathrm{mg} / \mathrm{kg}$ to $0.534 \mathrm{mg} / \mathrm{kg}$, $0.398 \mathrm{mg} / \mathrm{kg}$ and $0.4212 \mathrm{mg} / \mathrm{kg}$ respectively.

This suggests that only iron pot added copper to the food sample although in a very minute concentration and doesn't pose any health risk. Samples milled with mortar and pestle increased from 0.07 $\mathrm{mg} / \mathrm{kg}$ to $0.249 \mathrm{mg} / \mathrm{kg}, 0.171 \mathrm{mg} / \mathrm{kg}, 0.1462 \mathrm{mg} / \mathrm{kg}$ while samples milled with grinding stone increased from 0.1 $\mathrm{mg} / \mathrm{kg}$ to $0.1762 \mathrm{mg} / \mathrm{kg}, 0.1752 \mathrm{mg} / \mathrm{kg}, 0.1212 \mathrm{mg} / \mathrm{kg}$ respectively for Lycopersicon esculentum. In the case of mortar and pestle milled citrullus lanatus, copper values increased from $0.4822 \mathrm{mg} / \mathrm{kg}$ to $0.79 \mathrm{mg} / \mathrm{kg}, 0.6192$ $\mathrm{mg} / \mathrm{kg}$ and $0.3262 \mathrm{mg} / \mathrm{kg}$ while samples milled with grinding stone increased from $0.3332 \mathrm{mg} / \mathrm{kg}$ to 0.7682 $\mathrm{mg} / \mathrm{kg}, 0.48 \mathrm{mg} / \mathrm{kg}$ and $0.29 \mathrm{mg} / \mathrm{kg}$, respectively.

Conclusively, none of the milling techniques and cookwares included in this study poses a risk of $\mathrm{Cu}$ intoxication. Lead was not detected in any of the samples analyzed. Aluminium was observed only in samples cooked with locally iron pot. This indicates that the iron pot is directly responsible for this contamination.T he values range from $0.4 \mathrm{mg} / \mathrm{kg}-1.63 \mathrm{mg} / \mathrm{kg}$, therefore there's risk of Al toxicity because the upper range exceeds the WHO limit of $1 \mathrm{mg} / \mathrm{kg}$. Cadmium was only detected in samples milled with grinding stone and also in samples cooked with earthern ware pot and iron pot. However, values of contamination are low so there's minimal risk of cadmium intoxication.

\section{REFERENCES}

[1] Bharathi, P., M. Govindaraju, A.P. Palanisamy,K. Sambamurti and K.S. Rao, 2008. Molecular toxicity of aluminum in relation to neuro degeneration. Indian J. Med. Res., 128(4): 545-556.

[2] Cabrera.C, F.Lloris,R. Gimenez, M. Olalla and C. Lopez, 2003. Mineral content in legume and nuts: Contribution to the spanish dietary intake. Sci. Total Environ, 308: 1-14.

[3] Dabonne .S, B.P.K. Koffi, E.J.P. Kouadio, A.G. Koffi, E.A. Due and L.P. Kouame,2010. Traditional Utensils: Potential Sources of Poisoning by Heavy Metals. British Journal of Pharmacology and Toxicology 1(2): 90-92. 
[4] Elekofehinti O. O, Omotuyi I. O,Olaremu A. G and Abayomi T. G (2012).Heavy metals distribution and lipid profile in the stomach of cow grazed in Akungba-Akoko,Ondo State, Nigeria. African Journal of Biochemistry Research 6(11):146-149

[5] Jigam,A.A; Bukar E. N.Dauda; Jimoh T;Hauwa N. Yusuf and Umar Z.T, 2011.Determination of copper, zinc, lead and some biochemical parameters in fresh cow milk from different locations in Niger State, Nigeria. African Journal of Food Science Vol. 5(3), pp. 156-160.

[6] Jimoh, W.L.O and Mahmud Imam Mohammed, 2012. Assessment of Cadmium and Lead in Soil and Tomatoes Grown in Irrigated Farmland of the Kaduna Metropolis Nigeria. Research Journal of Environmental and Earth Sciences, 4(1): 55-59.

[7] Llobet JM, Falco G, Casas G, Teixido A and JL Domingo,2003.Concentrations of arsenic, cadmium, mercury and lead in common foods and estimated daily intake by children, adolescents, adults and seniors of Catalonia, Spain. Spain. J. Agric. Food Chem; 51: $838-842$.

[8] Miu, A.C. and O. Beng, 2006. Aluminum and Alzheimer's disease: A new look. J. Alzheimers Disease., 10(2-3):179-201.

[9] Murkovic M, Hillebrand A, Winkler J, Leitner E, Pfannhauser W (1996).Variability of Fatty Acid Content in Pumpkin Seeds.(Cucurbita.PepoL.). Zeitschrift-fuer-LebensmittelUntersuchung-und-Forschun. 203(3): 216

[10] Official method of Analysis (AOAC) 2006.Association of official analytical chemists(AOAC)Washington, D.C. $23^{\text {rd }}$ Edition

[11] Pennington JAT 2000. Total diet studies-experiences in the United States. J. Food Composit. Analysis. 13: 539-544

[12] Rajwanshi P; Singh V; Gupta M.K; Dass S, 1997.Leaching of aluminum from cookwares: A review. Environmental Geochemistry and health; 19 (1) 1-18

[13] Rajwanshi P; V. Singh; M. K. Gupta; R. Shrivastav; V. Subramanian; S. Prakash; S. Dass, 1999. Aluminum Leaching from Surrogate Aluminum Food Containers Under Different pH and Fluoride Concentration. Bull. Environ. Contam. Toxicol. 63:271276 .

[14] Richard C. Ehiri; Ugochukwu G. Megwa and Omaka N. Omaka, 2010.Food grinding stones as a source of heavy metal contamination of diets. Journal of Sciences and Multidisciplinary Research Vol 2.

[15] Somers, E. 1974. The toxic potential of trace metals in foods. Journal of Food Science, 39: 215-217.

[16] Vogel, A.I. (2002). Qualitative Inorganic Analysis ( $7^{\text {th }}$ Edition). Thompson Press. Pp 250-258

[17] WHO. World Health Organization. Toxicological evaluation of certain food additives and food contaminants WHO Food series 18 , Geneva 2006.

[18] Yahaya, D.B ; D.A. Aremu and I. Abdullahi,2012. Investigation of Metal Contaminants in Locally Ground Foods (Beans and Tomatoes).Journal of Emerging Trends in Engineering and Applied Sciences (JETEAS) 3(1):339-343.

[19] Younis YM, Ghirmay S, Al-Shihry SS (2000). African CucurbitapepoL.Properties of Seed and Variability in Fatty Acid Composition of Seed. 